\title{
PROGRAM PSIKOEDUKASI OPTIMALISASI TUMBUH KEMBANG ANAK MELALUI SENSORY INTEGRASI
}

\author{
Mauna \\ Fakultas Pendidikan Psikologi, Universitas Negeri Jakarta \\ mauna@unj.ac.id
}

\begin{abstract}
All children experience the process of growth and development in life. In order to reach optimal development, the child needs to get the appropriate stimulation provided with the right method. At the age of 0 to 7 years, children learn to use limbs so that the most appropriate stimulation for children aged 0 to 7 years is to use limbs as a medium of learning. This is in line with the techniques performed on sensory integration programs. But unfortunately not many parents know this. This issue often creates problems in child development. The purpose of this community service is to raise the awareness of parents to conduct teaching and learning process in ways appropriate to the age and stages of development owned by children so that children can be optimally developed. This activity is done by making activity planning, determining the location of activities and doing psychoeducation program on the parents of children at Darul Syifa Wal Aitam Foundation that located at Kranji, Bekasi. This activity is an attempt to improve parental knowledge about the importance of sensory integration and the impact it gains when the child's sensory is not well integrated. The benefit of this community service is the increased knowledge of parents about the use of sensory integration methods so that it can be used to optimize the growth of their children.
\end{abstract}

Keywords: Sensory Integration, Parents, Psycho-education, Optimizing Child's Development

\begin{abstract}
ABSTRAK
Semua anak mengalami proses pertumbuhan dan perkembangan dalam hidupnya. Agar perkembangannya dapat optimal, anak perlu mendapatkan stimulasi yang sesuai yang diberikan dengan metode yang tepat. Di usia 0 sampai 7 tahun anak belajar menggunakan anggota tubuhnya sehingga pemberian stimulasi yang paling tepat untuk anak usia 0 sampai 7 tahun adalah dengan menggunakan anggota tubuhnya sebagai media pembelajaran. Hal ini senada dengan teknik-teknik yang dilakukan pada program sensory integrasi. Namun sayangnya belum banyak orang tua yang mengetahui hal ini sehingga sering muncul permasalahan dalam perkembangan anak. Tujuan pengabdian masyarakat ini adalah meningkatkan kesadaran orangtua untuk melakukan proses belajar mengajar dengan cara-cara yang sesuai dengan usia dan tahapan perkembangan yang dimiliki oleh anak sehingga anak dapat berkembang dengan optimal. Kegiatan ini dilakukan dengan membuat perencanaan kegiatan, menentukan lokasi kegiatan dan melakukan program psikoedukasi pada orangtua anak-anak pada yayasan Darul Syifa Wal Aitam Kranji, Bekasi. Kegiatan ini sebagai usaha untuk meningkatkan pengetahuan orangtua tentang pentingnya sensori integrasi dan dampak yang didapatkan apabila sensori anak tidak terintegrasi dengan baik. Manfaat dari pengabdian ini adalah meningkatnya pengetahuan orang tua tentang penggunaan metode sensori integrasi sehingga dapat digunakan untuk mengoptimalkan tumbuh kembang anakanaknya .
\end{abstract}

Kata Kunci: Sensori Integrasi; Orangtua ; Psikoedukasi; Optimalisasi Tumbuh Kembang

\section{PENDAHULUAN}

Semua anak mengalami proses pertumbuhan dan perkembangan dalam hidupnya. Pertumbuhan adalah bertambahnya ukuran-ukuran fisik, seperti tinggi badan, berat badan, dan lingkar kepala. Perkembangan, bertambahnya struktur dan fungsi tubuh yang lebih kompleks dan sifatnya kualitatif, misalnya perkembangan bicara. Dari anak yang tidak mengenal bahasa dan hanya bisa menangis untuk mengomunikasikan segala kebutuhannya, hingga dia lancar bercerita dengan menggunakan kosa kata yang bervariasi dan aturan bahasa yang tepat.

Perkembangan tidak selamanya berjalan mulus. Keterlambatan perkembangan adalah ketika anak tidak menunjukkan pencapaian perkembangan sesuai tahapan usianya, atau yang biasa dikenal dengan istilah milestones.

Jurnal Sarwahita Vol. 14 No. 01 Tahun 2017| 48 
Contoh milestones adalah tersenyum sosial di usia 2 bulan, mengangkat kepala di usia 3 bulan, memegang benda kecil dengan ibu jari dan telunjuk di usia 7-10 bulan, dan mengucapkan kata pertama antara 12-15 bulan. Penyebab keterlambatan perkembangan bisa karena faktor situasional atau bawaan. Contohnya, faktor situasional yang membuat anak terlambat bicara bisa karena kurang stimulasi (jarang diajak bicara; bingung karena orang-orang terdekatnya memakai bahasa berbeda-beda), atau karena faktor bawaan seperti mental retardasi (Berk, 2003).

Stimulasi akan menjadi tepat ketika diberikan di waktu dan cara yang tepat. Yang dimaksud di waktu yang tepat adalah diberikan di saat anak sudah siap. Sebagai contoh memberikan stimulasi untuk mengenal huruf saat anak sudah menguasai ketrampilan dasar membedakan bentuk-bentuk geometris dasar. Sedangkan yang dimaksud cara yang tepat adalah memberikan stimulasi dengan metode yang sesuai.

Metode yang paling tepat untuk memberikan stimulasi anak usia 0 sampai dengan 7 tahun adalah metode sensori. Metode sensori menjadi metode paling efektif karena di usia sampai dengan 7 tahun anak belajar menggunakan anggota tubuhnya. Dengan menggunakan anggota tubuh anak lebih mudah mempelajari banyak hal karena tahap perkembangan kognitif mereka berada pada tahapan sensori motor (Ayres, 2005).

Sayangnya masih banyak orangtua dan guru yang tidak mengetahui hal ini sehingga anak diberikan stimulasi dengan cara-cara yang tidak sesuai seperti yang dianggap belajar adalah ketika anak memegang pensil dan menulis di kertas atau menyelesaikan pekerjaannya di kertas. Selain cara yang tidak sesuai masih banyak juga pemberian stimulasi di waktu yang tidak tepat sehingga berakibat pada perkembangan anak. Banyaknya kesalahan dalam cara dan waktu pemberian stimulasi pada anak meningkatkan masalah psikologis yang dialami anak dalam perkembangannya seperti kecemasan dalam belajar, fobia sekolah, anak karbitan, dan masalah-masalah lainnya.
Untuk meminimalisir semua masalah yang akhir-akhir ini mengalami peningkatan maka dianggap perlu mengadakan psikoedukasi tentang optimalisasi perkembangan anak melalui sensory integrasi.

\section{METODE PELAKSANAAN}

Metode yang digunakan dalam pemecahan permasalahan termasuk metode analisis. Metode-metode yang digunakan dalam pelaksanaan kegiatan ini dituliskan pada bagian ini.

Langkah pertama yang dilakukan adalah melakukan analisis kebutuhan terhadap masyarakat dengan melakukan wawancara terhadap pimpinan yayasan dan beberapa orang tua.

Setelah menganalisa permasalahan yang ada di yayasan, maka dikumpulkan bahanbahan yang terkait dengan perkembangan anak dan sensory integrasi

Langkah ketiga yang dilakukan adalah melaksanakan kegiatan berupa seminar dilanjutkan dengan kegiatan workshop kegiatan bermain permainan yang dapat mengoptimalkan perkembangan anak melalui sensory integrasi kepada orang tua anak-anak di Yayasan Darul Syifa Wal Aitam, Kranji, Bekasi.

Evaluasi proses pembelajaran dilakukan dengan cara melakukan uji validitas tampang dan isi (face and content validity) program dengan melakukan uji ahli (expert judgement) dan melakukan interater reliability. Selain itu evaluasi secara kualitatif juga dilakukan dengan mengadakan wawancara sebelum dan sesudah pelaksanaan program terhadap orangtua dan perwakilan yayasan.

\section{HASIL DAN PEMBAHASAN}

Pengabdian masyarakat yang dilakukan di Yayasan Darul Syifa Wal Aitam, Kranji, Bekasi memberikan hasil yang positif terlihat dari adanya partisipasi aktif dari orangtua yang hadir, serta pemimpin dan pembina yayasan. Partisipasi aktif ditunjukkan dengan banyaknya pertanyaan yang diajukan tentang masalah yang dialami anak-anak, memperhatikan dengan sungguh-sungguh selama psikoedukasi berlangsung dan 
kemauan untuk terlibat dalam pelaksanaan uji coba (roleplay) kegiatan bermain sensori integrasi.

Baik orangtua maupun pemimpin dan pembina yayasan terlibat secara penuh dan dengan antuasiasme yang tinggi mengikuti kegiatan uji coba (roleplay) dengan memperagakan peran sebagai orangtua dan anak secara bergantian saat mencoba permainan-permainan yang dapat menggunakan metode sensori sebagai bahan pembelajaran bagi anak.

Mendidik anak agar mencapai perkembangan yang optimal tentulah bukan perkara yang mudah karena kekurangan pengetahuan orangtua tentang metode yang paling sesuai digunakan untuk anak di usia tertentu.

Penggunaan metode sensory integrasi untuk mendidik anak di usia 0 sd 7 tahun dirasa sebagai sarana belajar yang paling sesuai karena di usia ini anak sedang dalam tahapan belajar menggunakan anggota tubuhnya.

Program psikoedukasi dirasa telah meningkatkan pengetahuan orangtua tentang apa itu sensori integrasi dan bagaimana penggunaannya untuk mengoptimalkan tumbuh kembang anak. Hal ini dibuktikan dengan meningkatnya pengetahuan orangtua tentang metode sesnori integrasi dan manfaatnya untuk mengoptimalkan tumbuh kembang anak-anak. Pengetahuan yang meningkat ini terlihat dari perubahan hasil jawaban wawancara yang dilakukan sebelum dan setelah kegiatan berlangsung kepada orangtua, pemimpin dan pembina yayasan. Sedangkan kegiatan uji coba (roleplay) menjadikan orangtua mempunyai pengalaman langsung tentang betapa mudahnya dan menyenangkan proses belajar menggunakan anggota tubuh sebagai bagain dari metode sensori integrasi. Pengalaman yang menyenangkan ini membuat orangtua, pemimpin dan pembina yayasan merasa tidak mengalami kendala yang berarti ketika menerapkan metode sensori integrasi untuk melakukan pembelajaran terhadap anak-anak yang berusia 0 sampai dengan 7 tahun.

\section{PENUTUP}

\section{A. Kesimpulan}

Metode sensori integrasi telah terbukti menjadi salah satu metode yang tepat untuk proses pembelajaran anak usia 0 sampai dengan 7 tahun. Metode ini dianggap tepat karena sesuai dengan tahapan perkembangan kognitif anak yang menjadi dasar dalam proses pembelajaran anak. Banyaknya permasalahan yang muncul akhir-akhir ini di dunia pendidikan terutama pendidikan anak usia dini dan pendidikan dasar. Kebanyakan permasalahan yang muncul terkait dengan kekurangsesuaian metode pembelajaran yang digunakan terhadap anak. Akibatnya anak menjadi malas belajar, mengalami masalah dalam belajar dan mengalami masalah dalam perkembangannya.

Sensori integrasi merupakan metode yang melibatkan penggunaan anggota tubuh dalam belajar sehingga sesuai dengan tahapan perkembangan berpikir pada usia tersebut. Proses belajar yang sesuai dengan tahapan perkembangan anak terbukti meminimalisir masalah-masalah perkembangan anak terkait proses belajarnya.

Sensori integrasi juga bermanfaat untuk mengatasi kasus-kasus permasalahan perkembangan lainnya seperti Pervasive Developmental Disorder,(PDD) ADHD, Speech Delay, Gloobal Developmental Delay, (GDD), Sensory Processing Disorder (SPD) dan dapat juga digunakan pada anak yang tidak berkebutuhan khusus untuk mengoptimalkan perkembangannya. Dalam kasus-kasus gangguan perkembangan yang telah disebutkan diatas, sensori integrasi dipakai sebagai sarana untuk mengintegrasikan sensori anak yang belum terintegrasi dengan baik sehingga anak bisa lebih adaptif ketika menghadapi lingkungannya. Seperti anak yang sangat takut menginjak rumput ketika sudah mendapatkan beberapa kali sesi terapi sensori integrasi maka anak tersebut berani menginjak rumput tanpa harus histeris. Sehingga sensori integrasi membuat anak menjadi lebih adaptif dan lebih nyaman berada di lingkungan sekitarnya. 
Metode-metode sensori integrasi yang berasal dari terapi sensori integrasi juga dapat diterapkan dalam proses pembelajaran anak sehari-hari. Jika pembelajaran pada anak usia 0 sampai dengan 7 tahun menggunakan metode sensori integrasi maka anak dapat menjadi lebih tenang, lebih fokus, lebih menikmati proses belajar dan lebih adaptif terhadap lingkungannya sehingga proses perkembangannya dapat mejadi lebih optimal.

\section{B. Saran}

Program psikoedukasi sebaiknya dilakukan secara berkesinambungan sehingga terdapat tahapan-tahapan yang lebih banyak mengandung praktek langsung dan adanya umpan balik setelah mempraktekkannya secara langsung terhadap anak dalam pelaksanaan programnya. Rancangan tahapannya adalah melakukan program psikoedukasi sesi pertama, melakukan uji coba antar orang tua dengan orang tua pada sesi pertama, orangtua mempraktekkan program di rumah bersama anaknya, orangtua mengikuti sesi kedua program psikoedukasi yang berlangsung sebulan kemudian. Pada sesi kedua ini akan dibahas tentang kendala yang dialami orangt tua selama melaksanakan program, dilanjutkan diskusi yang dilakukan antar sesama orangtua dengan difasilitasi oleh pemberi materi sehingga diskusi tersebut menghasilkan formula penyelesaian dari kendala yang dialami orang tua. Setelah sesi kedua berakhir orang tua kembali mempraktekkan program kepada anaknya di rumah dengan sudah mendapatkan solusi akan kendala yang dihadapi saat mempraktekkan metode terhadap anaknya

Untuk lebih memaksimalkan hasil penerapan metode sensori integrasi, orangtua harus mengetahui tentang milestone perkembangan anak, tahapan belajar anak dan macammacam teknik yang dapat digunakan dalam menerapkan metode ini. Oleh karena itu pembuatan buku saku dengan bahasa yang mudah dipahami oleh orangtua dan berisi umpan balik dari orangtua yang telah menerapkan metode ini diharapkan dapat lebih mengoptimalkan hasil dari penerapan program ini.
Yang tidak kalah penting adalah kemauan orangtua dalam membimbing anaknya menjalani proses pembelajaran dirumah. Rumah adalah tempat anak menghabiskan waktu terbanyak dan orangtua adalah figur terdekat anak-anak sehingga belajar bersama orangtua dengan cara-cara yang menyenangkan akan meningkatkan minat belajar anak dan menjadikan anak nyaman dalam proses belajar. Hal ini akan meminimalisir stres pada anak sekaligus stres pada orangtua sebagai akibat penolakan belajar oleh anaknya atau ketika anak mengalami masalah pembelajaran yang lain. Untuk meningkatkan kemauan orangtua mendampingi proses belajar anak maka orangtua harus diberikan informasi tentang dampak yang mucul akibat kesalahan penggunaan metode dalam belajar, bukti-bukti pendukung yang menyatakan bahwa metode sensori adalah metode yang sesuai untuk digunakan anak usia 0 sampai 7 tahun dan umpan balik dari orangtua lain yang sudah mencoba menerapkan penggunaan metode sensori integrasi.

\section{DAFTAR PUSTAKA}

Ayres, J.A. (2005). Sensory Integration and The Child: Understanding Hidden Sensory Challenges (25 ${ }^{\text {th }}$ Anniversary Ed.). L.A.: Western Psychological Service.

Berk, E.L. (2003) Child Development. 6th Ed. Boston: Allyn and Bacon

Bundy, A.C., Lane, S.J. \& Murray, E.A. (2002). Sensory Integration Approach: Theory and Practice (2 ${ }^{\text {nd }}$ ed.). Philadelphia: F.A. Davis Company

Brewer,J.A. (2007) Introduction to Early Childhood Education (Preschool throughprimary Grades; Sixth Edition. USA; Pearson Education Inc. Developmentally

Greenspan, S.I. (1985): First Feeling: Milestones in The Emotional Development of Your Baby and Child, New Zealand, Penguin Group.

Gonzalez-Mena, J. \& Eyer, D.W. 2004. Infants, Toddlers, and Caregivers: A 
DOI: https://doi.org/10.21009/sarwahita.141.06

P-ISSN: 0216-7484

E-ISSN: 2597-8926

Curriculum of Respectful, Responsive Care and Education (6 ${ }^{\text {th }}$ ed.). New York: McGraw-Hill Companies, Inc.

Grob,R.,Schlesinger,M., Pace, A., Michnick, G\&Pasek,K.H.2017. Playing with Ideas: Evaluating the Impact of the Ultimate Block Party, a Collective Experiential Intervention to Enrich Perception of Play. Journal of Child Development 88(5)

Meins, E. 1997. Security of Attachment and The Social Development of Cognition. Hove: Psychology Press.

Papalia, D.E., Olds, S.W. \& Feldman, R.D. 2004. Human Development (5th ed). New York : Mc Graw-Hill.

Schaefer, C.E. \& Millman, H.L. 1981. How to Help Children with Common Problem. New York : Van Nostrand Reinhold Company Inc. 